\title{
CHALLENGES AND POSSIBILITIES FOR ENVIRONMENTALLY SOUND RECYCLING OF SHIPS AND COMPOSITE BOATS IN EUROPEAN UNION
}

\author{
Vitomir Premur*, Aleksandra Anić Vučinić ${ }^{*}$ Ivana Melnjak", Lucija Radetić* \\ ${ }^{*}$ University of Zagreb, Faculty of Geotechnical Engineering, Varaždin, Croatia \\ corresponding author: Ivana Melnjak, e-mail: imelnjak@gfv.hr
}

\begin{abstract}
In this paper are presented challenges that countries of European Union face when recycling ships and composite boats. European ship owners control over $40 \%$ of the world's merchant ship fleet, with Greece as the top ship-owning country globally. Nowadays, ship recycling is being regulated and positive progression was made towards it since steel industry belongs in world's top five and stable market and makes recycling of scrap metals from ships attractive. On the other hand, yachts, sailing boats and small boats are mainly made from composite materials because of their favourable properties, making them great investment, but end-of-life management is more complicated and not quite regulated by the law yet. Unlike commercially oriented ships, which are constantly in move and disposed when the maintenance costs of the vessel start to exceed possible revenue, old boats for recreational and tourism-oriented purposes most rarely move. Hundreds of thousands lie in marinas and are abandoned due to the maintenance costs thus discouraging the owners from keeping it. Hence, a growing number of marinas worldwide will have the problem of boat disposal in a sustainable way in the future. In this paper is given short summary on waste ships and boats management issues. The emphasis is on waste management of small composite boats.
\end{abstract}

Keywords: ship recycling, legislative, composite boat disposal

\section{INTRODUCTION}

In a globalized world, the world trade fleet plays a pivotal role in limiting transport costs [1]. Approximately $90-95 \%$ of international commercial goods are transported by the sea, which represents the most important link in the world manufacturers' global logistical chain. Thus, the shipping industry represents the smallest part of a product's cost, making the trade viable. The disposal of ships at their economic end-of-life has great significance for the continual renewal of the merchant marine fleet and for sustainable development [2]. Every year, around 1000 large ocean-going vessels such as oil tankers, cargo and container ships are sold for dismantling. More than $70 \%$ of these end-of-life vessels are not recycled properly but are run ashore on tidal beaches in South Asia where they are scrapped by a 
largely unprotected and unskilled workforce and ravage the coastal eco-system. Only a small number of ship owners take full responsibility for the clean and safe recycling of their end-of-life fleet by choosing modern yards such as those operating in the European Union (EU), China and Turkey, by ensuring third party certification and strict supervision of the recycling process [3]. The EU ship owners are responsible for around one third of the end-of-life tonnage beached in substandard yards in South Asia. Therefore, the EU has a particular responsibility to find effective solutions to ensure sustainable ship recycling since EU ship owners control around $40 \%$ of the world's merchant fleet [3, 4]. However, only $22 \%$ of vessels fly under the flag of EU Member State. This discrepancy relates to the use of 'flags of convenience', a flag of a country under which a ship is registered to avoid financial charges or implementation of international legislation and restrictive regulations in the owner's country regarding the environmental protection and workers' rights. Owners do not adhere to the 'polluter pays' principles, but follow a 'polluter profits' strategy by selling off old ships to developing countries that are unlikely to become the driving force for a change towards clean and safe ship recycling. Flags of convenience are hardly used while ships are operational, but at their end-of-life, ships are at low cost 'reflagged' [3]. All vessels at the end of their life should be treated according to principles of circular economy. They are built from various types of materials from which some are proclaimed to be hazardous to the environment. If there is no appropriate integrated system for the recycling or reusing of ship-related steel, machines, auxiliaries and even furnishings, such materials will remain unused and useless to the economy at the ship's end-of-life cycle [2]. The ship dismantling process is typically considered as an 'unclean' activity due to environmental implications that usually result from it [5]. Vessels are built from different materials which do not always make them favourable for recycling, especially if market for the recycled material does not exist. Not necessarily all new materials are environmentally friendly but sound environmentally oriented policy is protecting the environment with strict instructions what to do with end-of-life vessels. The problem occurs when not all vessels are treated equally, since they are differed by size and/or function. In general they are grouped by size (gross tonnage - GT) into four categories: small ships (100 GT to 499 GT), medium ships (500 GT to 24999 GT), large ships (25000 GT to 59999 GT) and very large ships ( $\geq 60000$ GT). Since the steel industry is one of the biggest industries in the world, it is anticipated that ships made from steel are more interesting for recycling because of the stable market, unlike other ships which are made of other long-lasting materials such as composite materials. Also, the size of large ships makes them wanted on the market because of the steel quantity. This is the reason why the European Commission has conducted many studies on the dismantling practices of end-of-life vessels primarily focused on large seagoing vessels of the commercial fleet. Many of the small ships (below 500 GT) generally do not trade internationally, and therefore are not covered by the international conventions. Even though they might seem less important than other fleets above $500 \mathrm{GT}$, in terms of the total number of vessels, small ships alone represent $37 \%$ by number, so their significance is considerable, although they represent only $1 \%$ by tonnage [6].

Figure 1 show an overview of the distribution of the world fleet, both in total numbers and in gross tonnage (based on The World Merchant Fleet in 2017 - Statistics from Equasis).

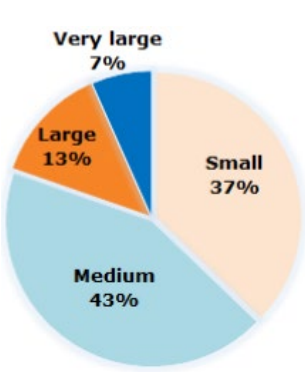

a)

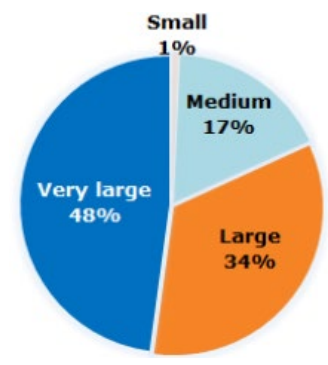

b)
Figure 1. a) world fleet: total number of ships, by size; b) world fleet: gross tonnage, by size [6] 
In Europe, a two-year "Boat Dismantling Insight by Generating Environmental Safety Training - DIGEST" project study was conducted. It was funded by the European Boating Industry trade association. The study found that amongst 7 million pleasure boats, $95 \%$ were built of fiberglass. The vast majority is shorter than $8 \mathrm{~m}$ and has an average life of 35 years. The International Council of Marine Industry Associations ICOMIA, an international umbrella association, has been gathering the nautical industry associations from many countries worldwide since 1966. According to its data, it is estimated that there are around 23 million boats in the world, and 16.4 million of them are in the US. It is estimated that $10 \%$ of these boats are no longer used regularly and that an additional $2 \%$ of boats will stop being used each year. Since the financial crisis in 2008, the number of abandoned boats increased. According to some other indicators, it is considered that there are around 40 million recreational boats in the world. If only $1 \%$ of boats annually become undesired, this means that about 400000 boats should be taken care of annually in the world [7].

\section{METHODS}

Vessels discussed in this paper are split in two categories, ships and boats. First category of ships includes all types of vessels above 500 gross tonnage (GT) and those that are mainly made of steel, while category of boats includes all types of recreational vessels and those made of different types of composite materials, size is not relevant. Boats made of metal such as aluminium or wooden boats are not specifically mentioned since end-of-life management of composite materials are lately of greater importance due to its possible negative environmental impact. Review and research articles published in the period from 2008 to 2018 were searched on Scopus and Science Direct databases. Articles were searched using the article title, abstract and keyword terms 'recycling' and 'boat' or 'ship' or 'end of life vessel' and 'composite materials'. To narrow the literature, abstracts and articles were screened. After screening and checking, analysis and synthesis of 18 articles was done.

\section{DISCUSSION}

Negative impacts on the environment of the ship dismantling activity can be minimized through valorisation by reusing, recycling or treatment of the materials and equipment removed from ships [5]. On average, the components that can be reused or recycled after being extracted from the end-of-life ships comprise about $96 \%$ of the ship's weight [8]. Depending on the type and purpose of the vessel, materials used in building vessels are steel, copper, copper alloys, aluminium, rubber, composite materials such as glass and/or polymer fibers reinforced plastics, and wood. Wood is oldest but now rarely used material; it can last a lifetime but it needs regular maintenance and replacement of beams to stop rotting. Steel is also extremely long lasting, if it is regularly maintained to stop corrosion [9]. Copper is mainly incorporated as alloy in parts that must be firm and resistant to sea water, while aluminium and its alloys due to its properties are used for the ship's structures that must be firm and reliable but light and it can be recycled indefinitely. Many boat parts are made from reinforced plastic (cross-linked polyester and fiberglass), as the combination results in a light yet strong material, which is good for crashing through waves, but often difficult and expensive to repair and not so good for recycling [10]. Most thermoplastics can also be recycled, although they are often degraded reducing their quality [9]. Nowadays, in vessel building, reinforced plastic has become strong competitor to traditional materials, since it is a good heat and electricity insulator, resistant to corrosion and chemical influence, resistant to atmospheric changes, resistant to destruction by plant and animal life (easier cleaning) and it is easily shaped $[11,12]$. 


\section{Ship recycling challenges}

The ship-demolition market initially flourished after the Second World War in the highly industrialized countries of the United States, Japan and the United Kingdom and subsequently expanded to other European countries like Spain and Turkey. In the 1970s, it moved towards East Asia and in the 1980s it has been gradually relocated to Bangladesh, India and Pakistan - so called Indian Subcontinent, as well as in China. These two areas account for the vast majority of the recycled tonnage every year during the last decade, claiming justly to be the market leaders. In general, the primary reason for the geographical shift of this market through time has been the search for lowest labour costs and high regional demand for steel; hence, nowadays the industry is confined in developing countries where both of the above conditions are met [13]. Today, shipbreaking in South Asia is still taking place at the cost of environmental destruction and severe health risks for the workers and the local population exposed to these hazardous wastes, such as asbestos, heavy metals, polychlorinated biphenyl (PCB), polyaromatic hydrocarbons (PAH), and organotin like tributyltin (TBT) [14]. On Indian Subcontinent are few facilities for hazardous waste, therefore materials that cannot be recycled are usually dumped on the spot. The primary reason for this is the lack strict of marine environmental regulations in the developing countries [15]. Work conditions in breaking yards are uniformly difficult, dangerous, and potentially hazardous with operations that are not well suited for mechanization [16]. Ships have a long life cycle and will undergo many repairs and maintenance in their 20 - 30 years of operation and very little of this will be properly documented, especially after the age of 20 years, because their maintenance cost becomes exponential [13, 17]. Ships contain a wide range of materials, including composites, which are very difficult to separate and recycle. Therefore, some materials can be recycled and will create revenue, others need expensive treatment, for which costs are significant. The scrap value of a ship is a function both of the realizable value of the materials within the ship and cost of demolition, both are strongly influenced by the cost structures prevailing in the likely country of demolition [18]. The price is also affected by other factors like the amount and quality of the steel, the presence of metals such as copper or nickel, the equipment that can still be sold but problematic substances on board do not seem to affect the price [17]. Bangladesh, China, India, Pakistan and Turkey have the greatest market share for demolition in bulk carriers, gas carriers, container ships, and oil tankers respectively [19]. For the last 20 years, ship recycling yards in the five leading ship recycling countries (Bangladesh, China, India, Pakistan, and Turkey) have been recycling 97 $-98 \%$ of all the tonnage that is recycled in the world [20]. Beaching is the predominant method of ship recycling while second is pier breaking [21]. None of the sites used for ship dismantling on the Indian sub-continent has containment to prevent soil and water pollution, few have waste management facilities, and the treatment of waste rarely conforms to even minimum environmental standards [22].

\section{Ship recycling possibilities as an answer to challenges}

The International Maritime Organization (IMO) has adopted Ship Recycling Guidelines that provide advice to all participants in the recycling process. The guidelines refer to the use of a Green Passport designed to document all potentially hazardous materials on board and must be verified by the Government of the State Flag State. The list of hazardous substances is specific to each ship. Creating the Green Passport should begin during the construction phase of the ship and should contain a list of all potentially dangerous materials that are found in the ship, its equipment and facilities, the place where they are on the ship as well as their quantity. After completion of the construction, the Green Passport should be maintained throughout the entire marine life. Ship owners should maintain a Green Passport and add to it 
subsequent design and equipment changes. When the ship reaches its end-of-life, the Green passport will be handed over to the recycling plant. A 2016 EU study identified the Ship Recycling Licence as a promising way to ensure that EU-flagged ships were recycled responsibly - avoiding the environmental and labour issues that have plagued the industry on the Indian subcontinent. The Licence would involve ships calling at EU ports obtaining a prior licence and pay a fee that would be accumulated to bridge the financial gap between dismantling in a substandard yard and dismantling in a yard included on the European List at the end of the ship's lifetime [23].

\section{Boat recycling challenges}

There is not a single efficient (legal and technically effective) system in Europe that detects when a boat enters its stage of disuse and from this point, puts in place an efficient process of waste management [21]. The current and future waste management and environmental legislations require all engineering materials to be properly recovered and recycled [24].

To effectively recycle boats, it is necessary to identify their location and the type of boats, transport it, decontaminate by removing oils, fuels, liquids, batteries, chemicals and CFC or freon in refrigerators, dismantle, and take care of the recyclable parts. In the $85 \%$ of cases, when recyclable parts are extracted, the rest of boats are composites hulls (FRP) [21]. The International Council of Marine Industry Associations (ICOMIA) has estimated more than 6 million recreational crafts in Europe alone, and the larger percentage of these is constructed from fiberglass [25]. As EU regulations on landfilling restrict the disposal of fiberglass to landfill, recycling will become the only realistic option. Various fiberglass recycling technologies have been developed: mechanical recycling, thermal recycling, and chemical recycling [24, 26 - 29]. Mechanical recycling (crushing, grinding, milling) is the most obvious one, reducing material size to be reused in other products [27]. Some of the beneficial uses of fiberglass recyclate obtained from mechanical recycling are in manufacturing artificial woods [30 - 32], in bitumen-based road asphalt and roof covering sheets and in cementitious materials to improve their thermal and insulation properties [33], potential use as a replacement for virgin reinforcing materials in new thermoset composites [34], as short-fiber reinforcements in microconcrete [35]. On the other hand, recycling of the composite hulls has been problematic since market for recycled fiberglass is too small and fragmented, material has little value so the price for recycled fiberglass is too low to justify recycling process. Also, there must be large enough recycling centres in the country that will take in enough scrap fiberglass and dismantle enough fiberglass hulls to give manufacturers a reliable source of recycled fiberglass and a large enough market for recycled products to support those recycling centres [28]. Thermal recycling or pyrolysis involves heating up the FRP material in an inert atmosphere in order to recover the polymer material as oil. In chemical recycling method, chemicals are used to dissolve the resin content of the FRP. Incineration involves combustion of FRP for energy recovery [12]. Hence, landfilling seems to be the most common method or incineration in cogeneration plants [21]. Disposing a hull on landfill can be problematic if the owner of an end-of-life boat cannot afford the disposal fee [28]. These objects usually become a waste difficult to manage. Dumping or sinking boats in ports and meadows has been a common practice in certain areas of the Mediterranean coast. Identification numbers are often missing, the characteristics of small vessels, such as average lifespan, materials of construction including hazardous components and scrapping/recycling activities are not well documented [36].

After removing the engines and other parts, the fiberglass laminate represents the largest part of what remains of the boat. At present time there is no economically justified manner to recycle the fiberglass, therefore further 
development is needed in this area. The research project [37] has shown that fiberglass in average makes about $35 \%$ of the mass of a fiberglass boat of about 7 to $7.5 \mathrm{~m}$ in length [7].

\section{Boat recycling possibilities as an answer to challenges}

Although as a material fiberglass composites do not decay, they become brittle without rest value and are usually landfilled. This approach is considered unsustainable in the long run and already certain countries, such as Germany and the Netherlands, have regulations restricting the disposal of fiberglass to landfill [38]. Up to now, majority of marinas have been simply stocking abandoned boats in their storage areas [25] since most of them are for a long time without any kind of control and are considered legally as a hazardous waste according to the European Classification of Waste (ECW) [21]. Therefore, small end-oflife boats are often a liability rather than an asset, and this is the single biggest obstacle to the sale of new boats, the gigantic oversupply of used [36]. The recycled composite material cannot be used entirely to build new boats especially after 50 years of usage. The composites are degraded and do not have the same properties as when they were new and new fiberglass is extremely cheap. After crushing, the fibres are much shorter and do not retain their initial properties. On the other hand, they might be suitable for certain elements on the boat that do not require specific mechanical properties, for example the shower tray, cupboard doors, shelves or a mattress support [39]. In France a network of 52 yacht disposal points, where boats are turned in for cleaning, dismantling and are handed over to a recycling company, has been operating along the French coast since 2009 under the French Nautical Industries Association [28]. Sweden has a new scheme that estimates disposal of 2000 to 3000 boats per year [40]. Finland also offers a complete solution to boat owners (private and professional), while in Italy and United Kingdom some dismantling companies accept to dispose off boats, among other activities [41]. Norway, Denmark, Spain and Japan also recycle fiberglass hulls, and the Netherlands, which has around 600000 leisure craft dotted around its waterways, has several companies offering yacht disposal services [28]. The Republic of Croatia does not have a special program for the disposal of worn-out fiberglass boats. At the present moment it is not certain how many fiberglass boats need to be disposed of annually, but it can be guessed that a number is not large [7].

\section{EU legislative on shipbreaking}

The search for an effective solution to irresponsible shipbreaking has been on the EU's agenda for many years, resulting so far in the EU Ship Recycling Regulation (EU SSR No 1257/2013) [4]. From 31 December 2018, the recycling of all large sea-going vessels sailing under an EU flag can only take place in yards included in the European List of ship recycling facilities. The EU Ship Recycling Regulation is the only legally binding and comprehensive instrument on ship recycling in force in the world today, which aims to make ship recycling greener and safer. At the international level, the Hong Kong International Convention for the Safe and Environmentally Sound Recycling of Ships was adopted in 2009 but has not entered into force since a sufficient number of Parties did not ratify it. Owners of ships sailing under the flag of an EU country are legally obliged to have them dismantled in yards that are approved under EU health and environmental standards [42, 43]. New European ships and EU-flagged ships going for dismantling must also have on board an Inventory of Hazardous Materials (IHM) verified by the relevant administration or authority and specifying the location and approximate quantities of those materials. This obligation will also apply from 31 December 2020 to all existing ships sailing under the flag of Member States of the EU as well as to ships flying under the flag of a third country and calling at an EU port or anchorage. This will facilitate the recycling of vessels and reduce the presence of toxic 
materials on board ships [43]. Improving the legal framework at EU level, coupled with a logical and fair tax policy, will be helpful to bring order to the management of the boats out of use [21]. The European Commission maintains a list of facilities worldwide that operate in line with the standards for ship recycling set by the EU SRR [42]. The European List of ship recycling facilities that met the design, construction and operation requirements of the EU is currently made of 23 shipyards. They fulfil the strict requirements and as a result will have exclusive access to the recycling of ships flying under the flags of Member States of the Union. Turkey and United States are also listed on European List of ship recycling facilities [43]. In Republic of Croatia there are four big shipyards and none of them is on approved EU list for recycling. Croatia is not even a sporadically involved in any kind of ship-breaking activity, unlike other coastal countries. The potential of the Croatian shipyards lies in the possibility of the highly educated human potential and apply high standards of environmental protection, health and safety. In addition, capacity multiply exceeds today's production in relation to the 1980s. At the end of 2005, Croatian shipbuilding industry was on the fourth place according to the World Book of Orders. Since then, unfortunately world financial and economic crisis strongly affected this sector. The recycling plants that exist today in most countries are missing.

\section{CONCLUSION}

The current and future waste management and environmental legislations require all engineering materials to be properly recovered and recycled according to circular economy principles, e.g. end of life vessels. Vessels are built from different materials, which do not always make them favourable for recycling, especially if market for the recycled material does not exist. At the heart of the shiprecycling problem is the lack of effective international governance to achieve a global solution. The International Maritime
Organisation (IMO) has produced the Hong Kong International Convention for the Safe and Environmentally Sound Recycling of Ships (HKC), which remains unratified and uncertain in effect. Improving the legal framework at EU level, with EU Ship Recycling Regulation, coupled with a logical and fair tax policy, will be helpful to bring order to the management of the boats out of use. To assist ship owners in choosing a suitable destination for their end-of-life vessels, European Commission maintains a list of appropriate ship recycling facilities. Since there is no economically viable recycling method for the fiberglass which represents the largest single piece of the boat, the disposal of boats in a safe and environmentally sound way is very challenging. The potential of the Croatian shipyards to join EU list of yards for shipbreaking should also be investigated.

\section{REFERENCES}

[1] D.A. Devault, B. Beilvert, P. Winterton, Ship breaking or scuttling? A review of environmental, economic and forensic issues for decision support, Environmental Science Pollution Research 24(2017) 33, 25741-25774.

[2] Y.C. Chang, N. Wang, O.S. Durak, Ship recycling and marine pollution, Marine Pollution Bulletin 60(2010) 9, 13901396.

[3] P. Heidegger, I. Jenssen, D. Reuter, N. Mulinaris, F. Carlsson, What a difference a flag makes, NGO Shipbreaking Platform, Belgium, 2015. https://www.shipbreakingplatform.org/is sues-of-interest/focs/, Accessed: June 11, 2019.

[4] M. Sieker, R. Adams, Opinion of the European Economic and Social Committee on 'Shipbreaking and the recycling society', Official Journal of the European Union, C34/38, February 2017.

[5] S. Carvalho, P. Antão, C.G. Soares, Modelling of environmental impacts of 
ship dismantling, Ships Offshore Structures 6(2011) 1-2, 161-173.

[6] European Maritime Safety Agency, "Equasis Statistics - The world merchant fleet in 2017".

http://www.emsa.europa.eu/equasisstatistics/items.html?cid=95\&id=472, Accessed: May 15, 2019.

[7] R. Dejhall, D. Legović, Disposal of Worn Out Fiberglass Recreational Boats, Journal of Maritime and Transportation Sciences 2(2018) Special edition 2, 143 153.

[8] K.P. Jain, J. Pruyn, Investigating the prospects of using a plasma gasification plant to improve the offer price of ships recycled on large-sized 'green' yards, Journal of Cleaner Production 171(2018), 1520-1531.

[9] J. Saltmarsh, Recycling Boats, Boat Gold Coast,

http://boatgoldcoast.com.au/recycling_b oats/, Accessed: May 15, 2019.

[10] B. Coxworth, New system created for recycling composite boats, 2011. https://newatlas.com/recyclingcomposite-boat-parts/18877/, Accessed: May 15, 2019.

[11] M. Ashby, K. Johnson, Material and Design, The Art and Science of Material Selection in Product Design, $3^{\text {rd }}$ Edition, Elsevier, 2014.

[12] S. Jayaram, K. Sivaprasad, C.G. Nandakumar, Recycling of FRP Boats, International Journal of Advanced Research in Science, Engineering and Technology 9(2018) 3, 244-252.

[13] N.D. Kagkarakis, A.G. Merikas, A. Merika, Modelling and forecasting the demolition market in shipping, Maritime Policy \& Management 43(2016) 8, 1021-1035.

[14] K.M.J. Iqbal, P. Heidegger, Pakistan Shipbreaking Outlook: The Way Forward for a Green Ship Recycling Industry - Environmental, Health and Safety Conditions, $1^{\text {st }}$ Edition, Sustainable Development Policy Institute and the NGO Shipbreaking Platform, Belgium, 2013. https://www.shipbreakingplatform.org/o ur-work/the-problem/pakistan/,

Accessed: May 15, 2019.

[15] S. Sinha, Ship Scrapping and the environment - the buck should stop!, Maritime Policy \& Management 25(1998) 4, 397-403.

[16] M. J. Kaiser, A Review of Ship Breaking and Rig Scrapping in the Gulf of Mexico, Ocean Development \& International Law 39(2008) 2, 178-199.

[17] L. Buxton, The market for ship demolition, Maritime Policy \& Management 18(1991) 2, 105-112.

[18] J.K. Choi, D. Kelley, S. Murphy, D. Thangamani, Economic and environmental perspectives of end-oflife ship management, Resources, Conservation and Recycling 107(2016), 82-91.

[19] M. Ventura Monsó, Guide on good scrapping and waste management practices for out-of-use boats, LIFE project Boatcycle, 2012.

http://ec.europa.eu/environment/life/proj ect/Projects/index.cfm?fuseaction=home . showFile\&rep $=$ file \&fil=BOATCYCLE Guide Good Scrapping.pdf, Accessed: May 15, 2019.

[20] N. Mikelis, Ship Recycling, in Sustainable Shipping, ed. H.N. Psaraftis Springer, 2019.

[21] European Commission, Green paper on better ship dismantling (2007/2279(INI). http://www.europarl.europa.eu/sides/get Doc.do? type $=$ REPORT\&reference $=\mathrm{A} 6-$ 2008-0156\&language $=\mathrm{EN}, \quad$ Accessed: May 15, 2019.

[22] E.U. Ship Recycling: No Financial Instrument, For Now, 2017, https://maritime-executive.com, Accessed: May 15, 2019.

[23] G. Neşer, Polymer Based Composites in Marine Use: History and Future Trends, Procedia Engineering 194(2017), 19-24.

[24] Future of yacht recycling conference Amsterdam, 2015.

http://yachtrecycling.org/wpcontent/uploads/2015/11/RobertoPerochio-1.pdf, Accessed: May 15, 2019. 
[25] Y. Yang, R. Boom, B. Irion, D.J. van Heerden, P. Kuiper, H. de Wit, Recycling of composite materials, Chemical Engineering Processing: Process Intensification 51(2012), 53-68.

[26] E. Sponberg, Recycling Dead Boats, Professional BoatBuilder Magazine, 2016.

https://www.proboat.com/2016/09/recycl ing-dead-boats/, Accessed: May 15, 2019.

[27] J. Flannery, The dead-boat disposal crunch - Trade Only Today, 2016. https://www.tradeonlytoday.com/dealers the-dead-boat-disposal-crunch, Accessed: May 15, 2019.

[28] Shipwrecks no more: Recycling old boats, 2011.

https://www.sciencedaily.com/releases/2 011/06/110609083228.htm, Accessed: May 15, 2019.

[29] K. Demura, Y. Ohama, T. Satoh, Properties of artificial woods using FRP powder, Disposal and recycling of organic and polymeric construction materials, Proceedings of International RILEM Workshop, Tokyo, March 1995, 169-178.

[30] K. Blizard, J. Portway, A wholly recycled structural plastic lumber incorporating scrap prepreg waste, Plastics in Building Construction 22(1998) 5, 8-12.

[31] S.D. George, S.H. Dillman, Recycled fiberglass composites as a reinforcing filler in post-consumer recycled HDPE plastic lumbe, in ANTEC 2000, 58 Annual Technical Conference, 2000, Orlando, Florida.

[32] G. Neşer, V. Aytekin, Modification of bitumen-based roof covering material by glass reinforced polyester recyclate, Journal of Material Cycles and Waste Management 17(2015) 3, 583-589.

[33] J. Palmer, O.R. Ghita, L. Savage, K.E. Evans, Successful closed-loop recycling of thermoset composites, Composites Part A: Applied Science and Manufacturing 40(2009) 4, 490-498.

[34] D. García, I. Vegas, I. Cacho, Mechanical recycling of GFRP waste as short-fiber reinforcements in microconcrete, Construction and Building Materials 64(2014), 293-300.

[35] European Commission and DG Environment, Recovery of obsolete vessels not used in the fishing trade, Denmark, 2011.

http://ec.europa.eu/environment/waste/sh

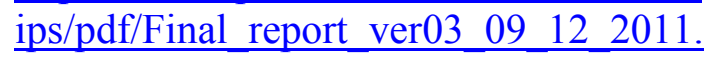
pdf, Accessed: May 15, 2019.

[36] G. Marsh, End-of-life boat disposal - a looming issue, Reinforced Plastics 57(2013) 5, 24-27.

[37] "BOAT digest - The Project." http://www.boatdigest.eu/theproject.asp, Accessed: June 11, 2019.

[38] Boat Recycling Faces Heavy Weather, 2017.

http://emag.nauticexpo.com/articlelong/boat-recycling-faces-heavyweather/, Accessed: May 15, 2019.

[39] Metstrade, Full line up for The Future of Yacht Recycling Conference, 2015. https://www.metstrade.com/news/article s/full-line-up-for-the-future-of-yachtrecycling-conference/, Accessed: May 16, 2019.

[40] Boat's end-of-life in ports, 2015, Boat DIGEST Final Conference Brussels, September 23, 2015

http://www.boatdigest.eu, Accessed: May 16, 2019.

[41] M. Matthaiakis, Brace for Impact: The E.U. Ship Recycling Regulation, The Maritime Executive, 2018.

https://www.maritimeexecutive.com/editorials/brace-forimpact-the-e-u-ship-recyclingregulation, Accessed: May 15, 2019.

[42] European Commission, Ship recycling facilities, 2016. http://ec.europa.eu/environment/waste/sh ips/list.htm, Accessed: May 16, 2019.

[43] NGO Shipbreaking, Implementation of the EU Ship Recycling Regulation No 1257/2013. 2018. https://www.shipbreakingplatform.org, Accessed: May 16, 2019. 